mately 2500 reports relating to beta-blockers other than practolol (Eraldin) have been received. There have been reports of rashes or dry eyes associated with the use of all the drugs in this group, but in most cases the signs and symptoms have cleared when treatment was withdrawn.

The Committee has received no evidence that any of the currently available beta blockers produce reactions of comparable severity to practolol, but in order to confirm this and also to exclude the possibility that serious adverse reactions of other types are occurring the Committee on Safety of Medicines would urge doctors to continue to report all untoward events occurring in patients on beta-blocking agents.

\begin{tabular}{|c|c|c|}
\hline Betacardone & (sotalol) & $\begin{array}{l}\text { Duncan Flockhart } \\
\text { and Co }\end{array}$ \\
\hline Betaloc & (metoprolol) & Astra Chemicals \\
\hline Blocadren & (timolol) & $\begin{array}{l}\text { Merck Sharp and } \\
\text { Dohme }\end{array}$ \\
\hline Inderal & (propranolol) & ICI \\
\hline Lopresor & (metoprolol) & $\begin{array}{l}\text { Geigy Pharma- } \\
\text { ceuticals }\end{array}$ \\
\hline Sectral & (acebutolol) & May and Baker \\
\hline Sotacor & (sotalol) & $\begin{array}{l}\text { Bristol } \\
\text { Laboratories }\end{array}$ \\
\hline Tenormin & (atenolol) & $\begin{array}{l}\text { Stuart Pharma- } \\
\text { ceuticals }\end{array}$ \\
\hline Trandate & (labetalol) & $\begin{array}{l}\text { Allen and } \\
\text { Hanburys }\end{array}$ \\
\hline Trasicor & (oxprenolol) & Ciba Laboratories \\
\hline Slow Trasicor & (oxprenolol) & Ciba Laboratories \\
\hline Visken & (pindolol) & Sandoz Products \\
\hline
\end{tabular}

London EC2

\section{What kind of cot death?}

SIR,-The reports on the aetiology of cot deaths in your leading article (18 March, p 671) and in the subsequent correspondence (22 April, p 1054; 6 May, p 1216) have not yet suggested a relationship between the state of mind of the mother before the event and the loss of her baby.

In six cases in which a patient has been referred to me for emotional problems in pregnancy or the puerperium the child of that pregnancy has died with a finding of cot death. Four of these babies were already on an at-risk register because of the mothers' expressed ambivalence to the baby and the extremely disrupted marital situation. Two had older siblings who had been previously taken into care for part of their lives because the mother was not caring for them properly. In three cases the local authority had been actually warned that something was likely to happen to the baby who eventually died.

What these cases had in common was an ambivalence towards the child who died and a home situation which was so disrupted by emotional problems that it was easy to see that symptoms in a baby could be overlooked or misinterpreted, feeds made up incompetently, and normal conditions of hygiene not adhered to. The question must be raised as to whether in a proportion of cot death the mental disturbance of the mother plays any part in the situation.

London W2

Elizabeth Tylden

SIR, - With reference to your leading article (18 March, p 671) I would like to put forward my observations on this subject.
I offer support to families in which a cot death has occurred. While listening to these families give an account of the final hours of the child's life I became aware that many of them had not actually been looked at for some hours. I then began asking when they had actually last seen their baby. I heard of a mother who had a child sleeping in her room, yet got up dressed, and went and made coffee withou glancing at the baby. Another family had a young baby in the car with them; after driving for some time without a backward glance at the carry-cot they unloaded the car before looking at the baby. A final example is of an 8week-old baby who had not been seen by its mother for 13 hours.

In these cases the social history has shown that there were other factors present that would lead one to believe that the baby was at some risk. It would appear that some mothers pay much less attention to their babies than others I feel that the mother's ambivalence about the conception, difficulties experienced during birth, problems in bonding, and the mother's depression may all lead to her feeling the need to distance herself from the child. I suspec that near-miss cot-death babies have mothers who are vigilant about their babies and are therefore more likely to notice them when they stop breathing and stimulate them. There may be a group of babies with poor respiratory control who also have less vigilant mothers, like the ones I have described, who are less likely to notice a pale, blue or apnoeic baby and so lose the opportunity to stimulate the child.

The fact that parents had not looked at very young babies for a long period before they were found dead occurred in a sufficient number of cases to make me wish to put this idea forward for consideration. I would be interested to hear from anyone who has similar observations as I hope to make a more detailed study.

\section{Department of Social Work,} Charing Cross Hospital (Fulham),
London W6

P E Hinton

\section{Vitamin $E$ and malignant hyperthermia}

SIR,-I wish to report a case of malignant hyperthermia occurring under general anaesthesia in a patient taking vitamin $\mathbf{E}$ which he had obtained from a health food store. The exact dosage is not known but was probably in the region of $200 \mathrm{IU}$ (equivalent to $200 \mathrm{mg}$ of $\alpha$-tocopheryl acetate) twice daily. A blood sample taken before the operation was later reported to have a serum vitamin $\mathrm{E}$ concentration of $19.4 \mathrm{mg} / \mathrm{l}$ (normal range $5 \cdot 2-11.4 \mathrm{mg} / \mathrm{l}$ ).

The patient, aged 69 , was to have a cystoscopy and Millin's prostatectomy. $\mathrm{He}$ had had an appendicectomy and inguinal hernia repair in "the 1940 s." Of the anaesthetics, it is known only that the induction agent was given rectally. He was given pethidine and promethazine premedication and anaesthetised with thiopentone, suxamethonium nitrous oxide, and halothane. The trachea was sprayed with lignocaine and intubated; relaxation was maintained with D-tubocurarine. After $1 \frac{3}{4} \mathrm{~h}$ a transfusion reaction was suspected because of a rise in pulse rate. The operation was completed, but because of the patient's general condition he was kept on the operating table and ventilated with oxygen. The rectal temperature $2 \mathrm{~h}$ after induction was $39 \mathrm{C}$ and remained static for the next $25 \mathrm{~min}$ when it suddenly rose, reaching $42 \mathrm{C}$ at the time of cardiac arrest, 2 h 50 min after induction. Arterial blood taken before the sudden rise in temperature showed pH 6.94, $\mathrm{PCO}_{2} 12.6 \mathrm{kPa}(94.7 \mathrm{~mm} \mathrm{Hg})$, and base excess $-9.8 \mathrm{mmol} / 1$. Treatment was atten $p$ ted with surface cooling, intravenous sodium bicarbonate, and dexamethasone but was unsuccessful.

Careful inquiry among the patient's seven siblings and their children has failed to reveal any death during anaesthesia, so a hereditary predisposition to malignant hyperthermia is unlikely. Dr F R Ellis of the Malignant Hyperthermia Investigation Unit has suggested that the vitamin $E$ which this patient was taking predisposed him to the development of the malignant hyperthermia syndrome. The purpose of this brief report is to alert anaesthetists to this possibility; they may wish to monitor temperatures during operations in patients who are taking vitamin $\mathbf{E}$ or health products such as wheatgerm oil which are rich in vitamin $\mathrm{E}$.

Philip James

\section{Anaesthetic Department,}

Anaesthetic Department,
Royal Isle of Wight County Hospital,
Ryde, IOW

\section{Psychological evaluation in cases of self-poisoning}

SIR,-The recent papers by $\mathrm{Dr} R$ Gardner and others (17 December, $p$ 1567) and by Dr D R Blake and Professor J R A Mitchell (22 April, $p$ 1032) highlight the increasing problem of self-poisoning and question the psychiatrist's role in assessment and follow-up

Dr Blake and Professor Mitchell even doubt that self-poisoners are patients in the conventional sense in that they have not asked for treatment; but they are surely as much patients as accident victims, for example, the majority of them more so, as we find that approximately $30 \%$ are currently receiving psychiatric treatment and $60 \%$ have consulted their general practitioner in the four weeks before the overdose. Indeed, selfpoisoning is often an expression of dissatisfaction with conventional methods of referral and treatment, so it is no surprise that in $\mathrm{Dr}$ Blake and Professor Mitchell's series the default rate in those referred to a psychiatric outpatient clinic was as high as $43 \%$.

Bearing in mind the findings of Barraclough et al that $41 \%$ of completed suicides had a previous episode of self-poisoning the two papers, far from invalidating the Hill Committee recommendations, would seem to underline their importance, in particular the need for designated treatment centres where all available help can be concentrated. Selfpoisoners are for the most part impulsive people with a low tolerance to stress; over $60 \%$ in our experience are facing an acute marital crisis, and delay in referral for even a few days can mean that the critical time for intervention has passed. Whether the help is to be given by nurses, physicians, or psychiatrists seems immaterial, but I agree with Dr Blake and Professor Mitchell that the same team should be involved throughout, and intervention is clearly simpler in a compact unit where information can be readily co-ordinated.

In this general hospital an average of 400 self-poisoners a year are admitted to a specialised four-bedded unit run jointly by physicians and psychiatrists where the nurses do much of the work of assessment, taking an initial history, talking to visitors, and offering a 24-h Samaritan-type service with phone-in or walk-in help following discharge. One or more psychiatrists attend daily and interview patients and relevant family members or when there are no relatives, the social worker, health visitor, or other key figures already in- 